\title{
PENGARUH KOMUNIKASI KELUARGA TERHADAP PENGUASAAN \\ BAHASA INGGRIS PESERTA DIDIK KELAS X DI SMK PGRI 1 TAMBUN KECAMATAN TAMBUN SELATAN KABUPATEN BEKASI
}

\author{
Depi Prihamdani \\ PGSD FKIP UBP Karawang \\ Email: depiprihamdani@ymail.co
}

\begin{abstract}
This research is motivated by the importance of the role of parents in creating a family communication. The research method is survey method with approach of regression studies that are part of this type of qualitative research correlational. The results of this study are a significant influence of independent variables X (Family Communication) on the dependent variable $Y$ (Achievement Learning English), family communication contributes to the achievement of learning English by 9.9\%. there are positive influence of independent variables $X$ (Communication families) on the dependent variable $Y$ (Achievement Learning English).
\end{abstract}

Keywords: Family communication, mastery of the English language

\begin{abstract}
Abstrak: Penelitian ini dilatarbelakangi oleh pentingnya peranan orang tua dalam menciptakan komunikasi keluarga. Metode penelitian yang dipakai adalah metode survey dengan pendekatan studi Regresi yang merupakan bagian dari jenis penelitian kualitatif korelasional. Hasil Penelitian ini terdapat pengaruh yang signifikan variabel bebas $\mathrm{X}$ (Komunikasi Keluarga) terhadap variabel terikat $\mathrm{Y}$ (Prestasi Belajar Bahasa Inggris), kontribusi komunikasi keluarga terhadap prestasi belajar Bahasa Inggris sebesar 9,9\%. terdapat pengaruh yang positif variabel bebas $\mathrm{X}$ (Komunikasi keluarga) terhadap variabel terikat Y (Prestasi Belajar Bahasa Inggris).
\end{abstract}

Kata kunci : Komunikasi keluarga, penguasaan bahasa Inggris 


\section{PENDAHULUAN}

Belajar pada hakikatnya adalah belajar untuk berfikir (Barnadib, 2000: 12). Beberapa definisi di atas dapat diartikan bahwa belajar merupakan proses yang dilakukan peserta didik untuk melatih pikiran dan kemampuan menganalisa dan serta menelaah permasalahan yang ada.

Menurut M. Sobry Sutikno dalam bukunya Menuju Pendidikan Bermutu (2004:3), “belajar sebagai suatu proses usaha yang dilakukan oleh seseorang untuk memperoleh suatu perubahan yang baru sebagai hasil pengalamannya sendiri dalam interaksi dengan lingkungannya." Dari pengertian tersebut dapat dikatakan bahwa hasil dari belajar ditandai dengan adanya perubahan yang terjadi dalam diri seseorang setelah melakukan kegiatan tertentu.

Prestasi belajar menurut Suharsimi Arikunto (1990:113), prestasi belajar adalah hasil akhir setelah mengalami proses belajar dimana tingkah laku itu tampak dalam bentuk perubahan yang dapat diamati dan diukur".
Sedangkan Benyamin S Bloom, sebagaimana dijabarkan Nana Sujana (1990:22), mengemukakan bahwa prestasi belajar dapat dibagi dalam tiga ranah yaitu:

1. Ranah kognitif berkenaan dengan hasil belajar, intelektual yang terdiri dari enam aspek, yaitu pengetahuan atau ingatan, pemahaman, aplikasi, analisa, sintesa dan evaluasi. Kedua aspek pertama disebut kognitif tingkat rendah dan berikutnya termasuk kognitif tingkat tinggi.

2. Ranah Afektif berkenaan dengan sikap yang terdiri dari lima aspek yaitu penerimaan, jawaban atau reaksi, penilaian, organisasi dan internalisasi.

3. Ranah psikomotorik berkenaan dengan hasil belajar atau prestasi belajar keterampilan dan kemampuan bertindak yang terdiri dari enam aspek, yaitu: gerakan reflek, keterampilan gerakan dasar, kemampuan konseptual, keharmonisan atau ketepatan, gerakan keterampilan komplek dan gerakan ekspresif dan interpretatif. 
Idealnya dalam pembelajaran di sekolah perubahan terhadap aspekaspek sebagaimana diuraikan di atas dapat benar-benar terealisir sehingga dapat dilakukan penilaian yang menyeluruh terhadap diri peserta didik, akan tetapi karena pengelompokkan karakteristik materi yang akan diajarkan pada setiap mata pelajaran tentunya akan ada perbedaan dalam mengukur tingkat kemampuan peserta didik dalam menguasai materi pelajaran. Namun demikian terdapat persamaan dalam cara mengukur tingkat prestasi peserta didik melalui suatu tes formatif maupun tes sumatif.

Berdasarkan tes tersebut peserta didik dapat mengetahui tingkat keberhasilan belajar sehingga dapat dijadikan sebagai referensi bagi proses belajar berikutnya. Sedangkan bagi guru data hasil belajar dapat dijadikan sebagai alat ukur tingkat keberhasilan mengajar, mengetahui sejauhmana pemahaman dan penguasaan peserta didik terhadap materi pengajaran yang telah diajarkan, sehingga dapat dijadikan referensi dalam menentukan langkah- langkah dalam proses pengajaran berikutnya.

Menurut Winkel, "Prestasi belajar" adalah perubahan-perubahan dalam pengetahuan, pemahaman, keterampilan dan nilai sikap yang bersifat konstan atau menetap (1996:15).

Prestasi belajar setiap peserta didik di berbagai jenjang sangat perlu untuk ditingkatkan, terutama bagi peserta didik SMK swasta kelas $\mathrm{X}$ yang mempelajari Bahasa Inggris. Dengan prestasi belajar yang tinggi, peserta didik akan memperoleh perhatian yang tinggi untuk bidang studi bahasa Inggris. Dengan perkembangan informasi dan teknologi yang semakin pesat, ditambah dengan semakin ketatnya persaingan dalam dunia pekerjaan, memacu peserta didik untuk menambah ilmu pengetahuan yang dimilikinya agar selalu dapat mengikuti perkembangan informasi serta dapat bersaing dalam memperoleh lapangan pekerjaan.

Kriteria ketuntasan minimum (KKM) merupakan instrumen penilaian prestasi belajar peserta didik. Prestasi belajar dikatakan 
tinggi apabila sudah dapat melampui batas kriteria ketuntasan minimal atau KKM, dapat pula dilihat dari prestasi ujian yang didapat peserta didik. Sebaliknya, prestasi belajar dikatakan rendah apabila belum mencapai batas kriteria ketuntasan minimal atau KKM, atau prestasi dalam ujian yang didapat nilainya rendah. Ada dua faktor yang dapat mempengaruhi pencapaian prestasi belajar siswa. Faktor tersebut adalah faktor internal dan faktor eksternal. Faktor internal adalah faktor yang berasal dari dalam diri peserta didik sendiri, dan faktor eksternal atau faktor yang berasal dari luar atau lingkungan.

Orang tua mempunyai peran yang sangat penting dalam membimbing dan mendidik anakanaknya. Menurut Kartono (1985), anak sebagai manusia yang belum sempurna perkembangannya dipengaruhi dan diarahkan orang tua untuk mencapai kedewasaan, baik secara fisik maupun secara rohani. Dengan kedewasaan tersebut, anak akan dapat menjadi manusia yang mampu mencapai tujuan hidupnya, yakni kebahagiaan di dunia dan di akhirat. Selain membimbing, orang tua juga harus meluangkan waktu untuk anak-anaknya.

Anak merupakan bagian dari keluarga yang secara sosial dan psikologis tidak terlepas dari pembinaan dan pendidikan orang tua, masyarakat dan lembaga pendidikan. Pembinaan dan pendidikan yang diberikan terhadap anak merupakan upaya untuk membentuk kreativitas anak baik melalui keilmuan maupun ketrampilan. Orang tua dalam suasana kehidupan keluarga harus berupaya menciptakan iklim yang kondusif bagi tumbuh kembang kepribadian dan kreativitas anak (Gamal, 2006).

Suasana komunikasi keluarga atau psychological atmosphere baik atau buruk, bagi individu yang tinggal dalam keluarga akan dapat dirasakan setiap waktu. Sebaliknya, anak yang tumbuh dari keluarga yang hubungan komunikasi antar anggota keluarganya kurang hangat bahkan tanpa komunikasi tidak mampu untuk menunjukkan prestasi belajar yang tinggi. Kebanyakan anak-anak yang mampu menunjukkan potensinya tumbuh dari keluarga yang sehat, disebabkan anak tersebut mempunyai 
keinginan yang kuat untuk membuktikan bahwa ia mampu menjadi yang terbaik.

Orang tua harus mampu mendorong anak untuk meningkatkan prestasi belajarnya dengan cara melakukan komunikasi yang baik, mengenali apa yang dia sukai dan ajak melakukan hal tersebut, serta menanamkan rasa percaya diri bahwa dia mampu meningkatkan prestasi belajarnya. "Kuncinya adalah mengetahui apa yang dapat membuat anak tertarik dan ingin belajar." Sifat dasar anak adalah senang belajar hal itu bisa terlihat sejak usia dini yang dimulai dari anak belajar berjalan, dia jatuh dan bangkit lagi atas kemauan sendiri.

Komunikasi keluarga adalah suasana afektif (melibatkan perasaanperasaan dan kasih sayang yang kuat) yang tercipta dalam suatu keluarga sebagai hasil dari adanya interaksi antar anggota keluarga dan akan dipahami dan dihayati oleh anak.

Dengan demikian menunjukkan bahwa komunikasi keluarga adalah proses kognitif seseorang tentang lingkungannya yakni kehidupan keluarga yang meliputi seluruh kegiatan dan keadaan yang terjadi di dalam keluarga serta hal-hal yang mengisi kehidupan bersama dalam keluarga. Orangtua mempunyai peran sangat penting dalam menciptakan komunikasi keluarga, mulai dari sikap dan perlakuan orangtua besar pengaruhnya terhadap kepribadian anak sehingga berpengaruh pula pada aktivitas anak dalam lingkungan.

\section{METODE PENELITIAN}

Metode yang dipakai adalah metode survey dengan pendekatan studi Regresi yang merupakan bagian dari jenis penelitian kualitatif korelasional. Penelitian dengan metode survey adalah penelitian yang dilakukan untuk mengetahui tentang sesuatu fenomena yang terjadi dalam masyarakat.

Keerlinger mengatakan bahwa penelitian survey adalah penelitian yang dilakukan pada populasi besar maupun kecil, tetapi data yang dipelajari adalah data dan sampel yang diambil dari populasi tersebut, sehingga ditemukan kejadiankejadian relatif, distribusi, dan hubungan antar variabel sosiologis maupun psikologis. Penelitian survey 
biasanya dilakukan untuk mengambil suatu generalisasi dan pengamatan yang tidak mendalam, tetapi generalisasi yang dilakukan bisa lebih akurat bila digunakan sampel yang representatif.

Model konstelasi permasalahan penelitian dapat dilihat pada gambar berikut ini:

$$
\text { X }
$$

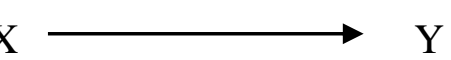

Keterangan:

$\mathrm{X}=$ Komunikasi keluarga
$\mathrm{Y}=$ Prestasi belajar

\section{HASIL PENELITIAN DAN PEMBAHASAN}

Deskripsi data secara keseluruhan dapat dilihat pada lampiran, pada bab IV ini ditampilkan deskripsi statistik dari hasil perhitungan dan pengujian yang dilakukan dengan bantuan komputer melalui program aplikasi SPSS 22, serta analisis dan intepretasinya.

Tabel 1

Deskripsi Data Penelitian

\begin{tabular}{|l|l|r|r|}
\hline \multicolumn{3}{|c|}{ Statistics } \\
\hline \multicolumn{2}{|c|}{$\mathrm{N}$} & Kom_Kel & Pres_B.Ing \\
\cline { 2 - 4 } & Missing & 40 & 40 \\
\hline Mean & 0 & 0 \\
\hline Median & 60,4000 & 42,8250 \\
\hline Mode & $59,000^{\mathrm{a}}$ & 41,5000 \\
\hline Std. Deviation & 6,43229 & 37,00 \\
\hline Variance & 41,374 & 10,59242 \\
\hline Minimum & 40,00 & 112,199 \\
\hline Maximum & 71,00 & 17,00 \\
\hline a. Multiple modes exist. The smallest value is shown \\
\hline
\end{tabular}

Skor Komunikasi keluarga peserta didik yang diperoleh dari para responden mempunyai rata-rata 60,40, dengan simpangan baku 6,432 , median sebesar 60,50, skor minimum 40, dan skor maksimum 71.
Dari deskripsi tersebut juga dapat dilihat bahwa antara nilai rata-rata dan median hampir sama, yaitu 60,40 dan 60,50. Hal ini menunjukkan bahwa data skor komunikasi keluarga pada penelitian ini cukup representatif. Sedangkan skor yang berada di atas rata-rata lebih banyak 
dibanding yang berada di bawah ratarata menunjukkan bahwa peserta didik yang mempunyai komunikasi keluarga yang tinggi lebih banyak dibanding yang rendah. Deskripsi data data tersebut bisa dilihat pada lampiran, sedangkan Histogram dari data tersebut bisa dilihat pada Gambar 4.1.

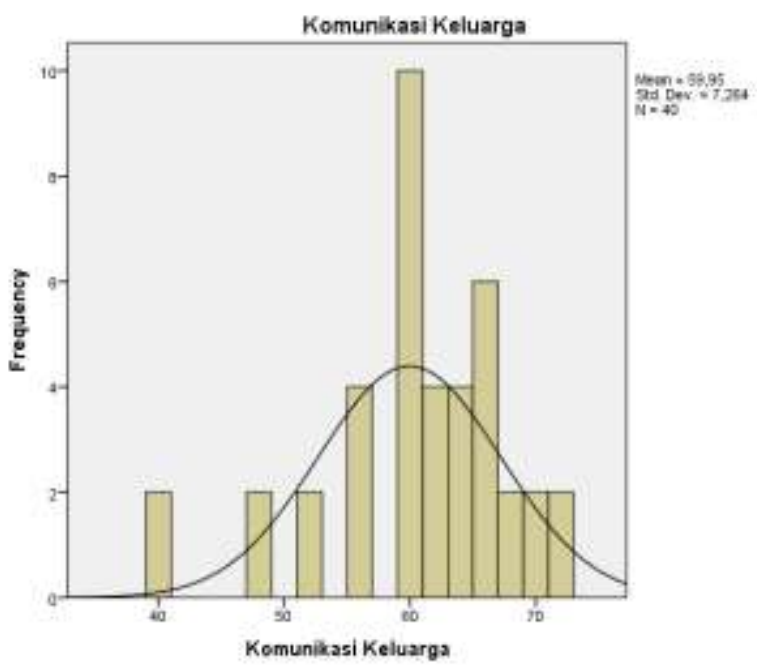

Gambar 4.1

Histogram Data Skor Komunikasi Keluarga

Dari tabel distribusi, serta histrogram dan poligon frekwensi dapat disimpulkan bahwa data skor skala komunikasi keluarga dalam penelitian ini memiliki sebaran yang cenderung normal.

Berdasarkan tabel 4.1. Data prestasi belajar peserta didik yang diperoleh dari para responden mempunyai rata-rata 42.83 dengan simpangan baku 10.592, median sebesar 41.50, skor minimum 17 dan skor maksimum 67. Hal ini menunjukkan bahwa rata-rata prestasi belajar siswa dari responden termasuk tinggi. Skor simpangan baku 10.592, menunjukkan perbedaan jawaban antar responden termasuk tinggi. Hal ini menunjukkan bahwa prestasi belajar peserta didik dari responden cukup beragam.

Dari deskripsi tersebut juga dapat dilihat bahwa antara nilai rata-rata dan dan nilai tengah (median) hampir sama, yaitu 42.83 dan 41.50. Hal ini menunjukkan bahwa data skor Prestasi belajar peserta didik pada penelitian ini cukup representatif. 
Sedangkan skor yang berada di atas rata-rata lebih banyak dibanding yang berada di bawah rata-rata, menunjukkan bahwa prestasi belajar peserta didik yang berada diatas rata- rata lebih banyak dibanding yang dibawah rata-rata.

Deskripsi data-data tersebut bisa dilihat pada lampiran, sedangkan histogram dari data tersebut bisa dilihat pada Gambar 4.2.

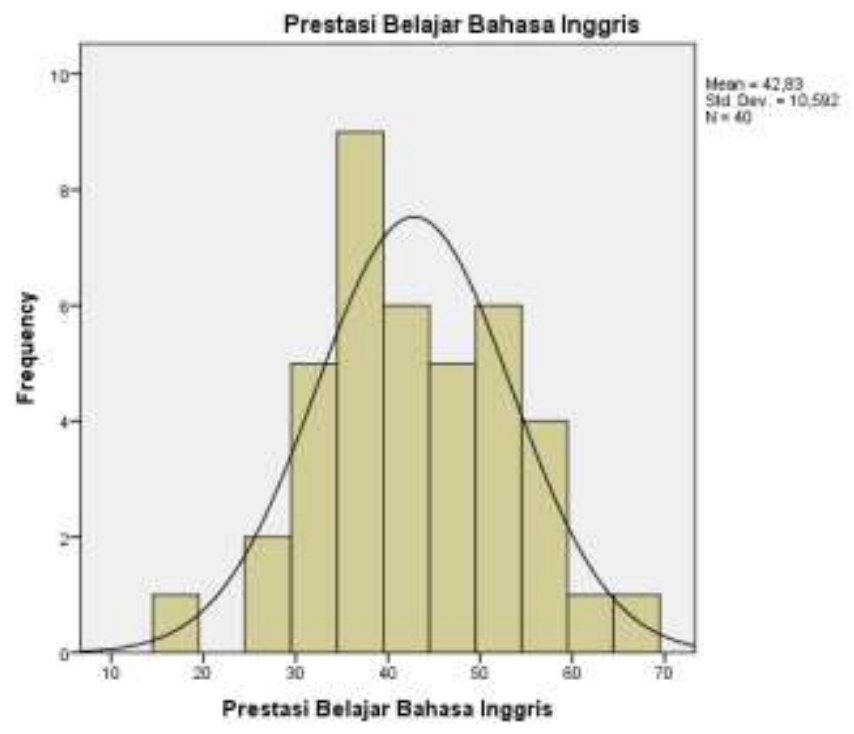

Gambar 4.2

Histogram Data Skor Prestasi Belajar Bahasa Inggris

Dari tabel distribusi, serta histrogram dan poligon frekwensi dapat disimpulkan bahwa data skor skala prestasi belajar siswa pada pelajaran Bahasa Inggris dalam penelitian ini memiliki sebaran yang cenderung normal.

Pengujian persyaratan analisis data yang dilakukan dalam penelitian ini adalah pengujian normalitas, homogenitas, dan linieritas garis regresi partial antara variabel bebas dan variabel terikat.

Pengujian normalitas data masing-masing sampel diuji melalui hipotesis berikut:

$\mathrm{H}_{0}$ : data pada sampel tersebut berdistribusi normal

$\mathrm{H}_{1}$ : data pada sampel tersebut tidak berdistribusi normal

Perhitungan dilakukan dengan bantuan komputer melalui program aplikasi SPSS 22. Menurut ketentuan 
yang ada pada program tersebut maka kriteria dari normalitas data adalah “jika $p$ value $\left(\right.$ sig) $>0.05$ maka $\mathrm{H}_{0}$ diterima", yang berarti data pada sampel tersebut berdistribusi normal. Nilai $p$ value (sig) adalah bilangan yang tertera pada kolom sig dalam tabel hasil/output perhitungan pengujian normalitas oleh program SPSS. Dalam hal ini digunakan metode Kolmogorov-Smirnov. Hasil perhitungan bisa dilihat pada Tabel

Tabel 4.2

Uji Normalitas Galat

One-Sample Kolmogorov-Smirnov Test

\begin{tabular}{|ll|r|r|}
\hline & & Kom_Kel & Pres_B.Ing \\
\hline N Normal Parameters ${ }^{\mathrm{a}, \mathrm{b}}$ & Mean & 40 & 40 \\
& Std. Deviation & 60,8500 & 42,8250 \\
Most Extreme Differences & Absolute &, 43752 & 10,59242 \\
& Positive &, 089 &, 134 \\
& Negative & -119 &, 134 \\
& &, 119 &,- 091 \\
Test Statistic & &, $162^{\mathrm{c}}$ &, 134 \\
Asymp. Sig. (2-tailed) & & &, $069^{\mathrm{c}}$ \\
\hline
\end{tabular}

a. Test distribution is Normal.

b. Calculated from data.

c. Lilliefors Significance Correction.

Pada tabel di atas terlihat bahwa nilai pada kolom Sig pada metode Kolmogorov-Smirnov untuk semua sampel lebih besar dari 0.05, sehingga
$\mathrm{H}_{0}$ diterima, dengan kata lain bahwa data dari semua sampel pada penelitian ini berdistribusi normal. 


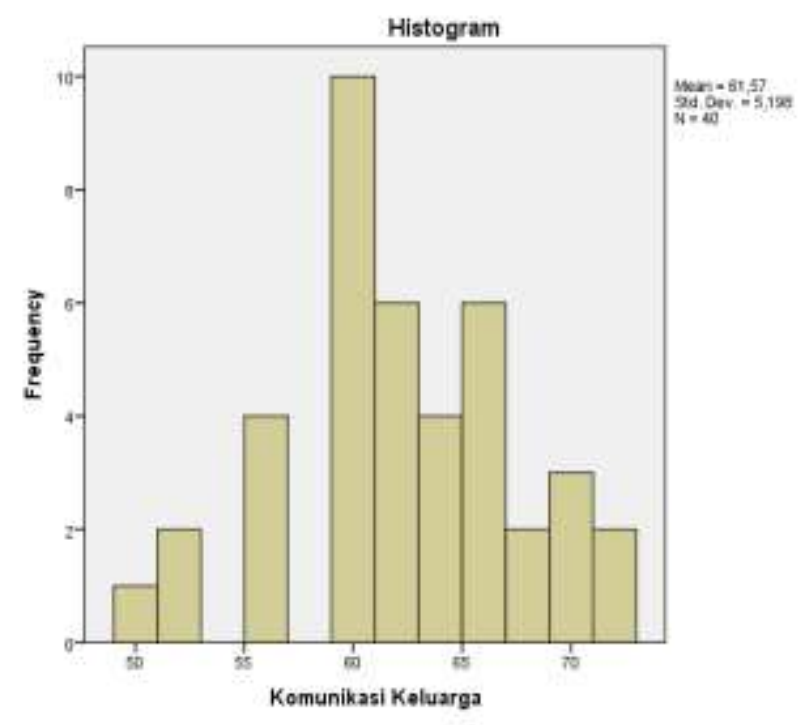

Gambar 4.3

Histogram Normalitas Galat Baku

Pengujian linieritas dalam penelitian ini digunakan hipotesis berikut:

$\mathrm{H}_{0}$ : garis regresi hubungan antara varibel $\mathrm{X}$ dan variabel $\mathrm{Y}$ linier

$\mathrm{H}_{1}$ : garis regresi hubungan antara varibel $\mathrm{X}$ dan variabel $\mathrm{Y}$ tidak linier

Perhitungan dilakukan dengan bantuan komputer melalui program aplikasi SPSS 22. Menurut ketentuan yang ada pada program tersebut maka kriteria dari normalitas data adalah “jika $p$ value $($ sig $)<0,05$ maka $\mathrm{H}_{0}$ diterima", yang berarti bahwa sampel-sampel tersebut berasal dari populasi yang homogen. Nilai $p$ value (sig) adalah bilangan yang tertera pada kolom sig baris Linierity dalam tabel ANOVA hasil perhitungan pengujian linieritas garis regresi oleh program SPSS.

Hasil perhitungan pengujian linieritas garis regresi hubungan antara variabel $\mathrm{X}$ dengan variabel $\mathrm{Y}$ bisa dilihat pada Tabel 4.3. 
Tabel 3

Rekapitulasi Hasil Pengujian Linieritas Garis Regresi Hubungan Antara Variabel X dengan Variabel Y

ANOVA Table

\begin{tabular}{|c|c|c|c|c|c|c|c|}
\hline & & & $\begin{array}{l}\text { Sum of } \\
\text { Squares }\end{array}$ & $\mathrm{df}$ & $\begin{array}{l}\text { Mean } \\
\text { Square }\end{array}$ & $F$ & Sig. \\
\hline \multirow[t]{5}{*}{$\begin{array}{l}\text { Kom_Kel * } \\
\text { Pres_B.Ing }\end{array}$} & \multirow{3}{*}{$\begin{array}{l}\text { Between } \\
\text { Groups }\end{array}$} & & 424,011 & 13 & 32,616 & 1,163 & , 357 \\
\hline & & Linearity & 11,268 & 1 & 11,268 & ,402 &, 532 \\
\hline & & $\begin{array}{l}\text { Deviation from } \\
\text { Linearity }\end{array}$ & 412,743 & 12 & 34,395 & 1,227 & ,318 \\
\hline & \multicolumn{2}{|c|}{ Within Groups } & 729,089 & 26 & 28,042 & & \\
\hline & \multicolumn{2}{|l|}{ Total } & 1153,100 & 39 & & & \\
\hline
\end{tabular}

Pada tabel di atas terlihat bahwa nilai pada kolom Sig baris deviation from Linierity $=0,318$ untuk semua sampel lebih dari 0,05 sehingga $\mathrm{H}_{0}$ diterima, dengan kata lain bahwa garis regresi hubungan antara varibel $\mathrm{X}$ dan variabel $\mathrm{Y}$ linier.
Pengujian hipotesis dilakukan seperti ketentuan yang tertulis pada metode penelitian. Hasil perhitungan dan pengujian bisa dilihat pada Tabel 4.5, Tabel 4.6, berikut:

Tabel 4.4

\section{Hasil Perhitungan Koefisien Korelasi Pengaruh Variabel X terhadap} Variabel Y

Model Summary ${ }^{b}$

\begin{tabular}{|c|c|c|c|c|c|c|c|c|c|}
\hline \multirow[b]{2}{*}{ Model } & \multirow[b]{2}{*}{$\mathrm{R}$} & \multirow[b]{2}{*}{$\begin{array}{c}\mathrm{R} \\
\text { Square }\end{array}$} & \multirow[b]{2}{*}{$\begin{array}{l}\text { Adjusted } \\
\text { R Square }\end{array}$} & \multirow{2}{*}{$\begin{array}{c}\text { Std. Error } \\
\text { of the } \\
\text { Estimate }\end{array}$} & \multicolumn{5}{|c|}{ Change Statistics } \\
\hline & & & & & $\begin{array}{l}\text { R Square } \\
\text { Change }\end{array}$ & $\begin{array}{c}\mathrm{F} \\
\text { Change }\end{array}$ & $\mathrm{df} 1$ & $\mathrm{df} 2$ & $\begin{array}{c}\text { Sig. F } \\
\text { Change }\end{array}$ \\
\hline 1 &, $099^{a}$ & ,010 &,- 016 & 10,67833 & ,010 & ,375 & 1 & 38 &, 544 \\
\hline
\end{tabular}

a. Predictors: (Constant), Kom_Kel

b. Dependent Variable: Pres_B.Ing 
Tabel 4.5

Rekapitulasi Hasil Perhitungan Persamaan Garis Regresi Pengaruh Variabel X terhadap Variabel Y

Coefficients $^{a}$

\begin{tabular}{|c|c|c|c|c|c|c|c|c|c|c|}
\hline \multirow[b]{2}{*}{ Model } & \multicolumn{2}{|c|}{$\begin{array}{c}\text { Unstandardized } \\
\text { Coefficients }\end{array}$} & $\begin{array}{c}\text { Standar } \\
\text { dized } \\
\text { Coeffici } \\
\text { ents }\end{array}$ & & & \multicolumn{3}{|c|}{ Correlations } & \multicolumn{2}{|c|}{$\begin{array}{l}\text { Collinearity } \\
\text { Statistics }\end{array}$} \\
\hline & B & $\begin{array}{l}\text { Std. } \\
\text { Error }\end{array}$ & Beta & $\mathrm{t}$ & Sig. & $\begin{array}{l}\text { Zero- } \\
\text { order }\end{array}$ & $\begin{array}{c}\text { Part } \\
\text { ial }\end{array}$ & Part & $\begin{array}{c}\text { Toleranc } \\
\text { e }\end{array}$ & VIF \\
\hline $\begin{array}{ll}1 \text { (Constan } \\
\text { t) } \\
\text { Kom_Kel }\end{array}$ & $\begin{array}{r}54,543 \\
-, 193\end{array}$ & $\begin{array}{r}19,209 \\
, 314\end{array}$ &,- 099 & $\begin{array}{l}2,839 \\
-, 612\end{array}$ & $\begin{array}{l}, 007 \\
, 544\end{array}$ &,- 099 & $\begin{array}{r}- \\
, 099\end{array}$ & ,099 & 1,000 & 1,000 \\
\hline
\end{tabular}

a. Dependent Variable: Pres_B.Ing

Tabel 4.6

Rekapitulasi Hasil Perhitungan Pengujian Signifikasi Koefisien Regresi Pengaruh Variabel X dengan Variabel $Y$

\begin{tabular}{|c|c|c|c|c|c|c|}
\hline \multicolumn{7}{|c|}{ ANOVA $^{a}$} \\
\hline \multicolumn{2}{|c|}{ Model } & $\begin{array}{l}\text { Sum of } \\
\text { Squares }\end{array}$ & $\mathrm{df}$ & Mean Square & $\mathrm{F}$ & Sig. \\
\hline & Regression & 42,760 & 1 & 42,760 & ,375 &, $544^{b}$ \\
\hline & Residual & 4333,015 & 38 & 114,027 & & \\
\hline & Total & 4375,775 & 39 & & & \\
\hline
\end{tabular}

a. Dependent Variable: Pres_B.Ing

b. Predictors: (Constant), Kom_Kel

Dari kedua tabel di atas, akan

$\mathrm{H}_{1}: \beta \neq 0$

diuji satu hipotesis yaitu:

Pengaruh Komunikasi Keluarga (X)

terhadap Prestasi Belajar Bahasa

Inggris Siswa (Y)

Hipotesis pengaruh ini adalah :

$\mathrm{H}_{0}: \beta=0$

artinya :

$\mathrm{H}_{0}$ : tidak terdapat pengaruh yang signifikan komunikasi keluarga (X) terhadap Prestasi belajar Bahasa Inggris ( $\mathrm{Y}$ ) 
$\mathrm{H}_{1}$ : terdapat pengaruh yang signifikan komunikasi keluarga (X) terhadap prestasi belajar Bahasa Inggris (Y)

Dari table $4.5 \mathrm{di}$ atas terlihat bahwa koefisien korelasi ganda pengaruh variabel bebas komunikasi keluarga $(\mathrm{X})$ terhadap prestasi belajar Bahasa Inggris (Y) adalah sebesar 0,099

Perhitungan

pengujian signifikansi koefisien korelasi ganda ini bisa dilihat di lampiran. Dari perhitungan tersebut diperoleh bahwa koefisien korelasi tersebut tidak signifikan, dengan kata lain bahwa tidak terdapat pengaruh yang signifikan variabel bebas komunikasi keluarga $(\mathrm{X})$ terhadap prestasi belajar Bahasa Inggris (Y) adalah sebesar 0,099

\section{Sedangkan} koefisien determinasinya sebesar $9,9 \%$ menunjukkan bahwa besarnya kontribusi komunikasi keluarga (X) terhadap prestasi belajar Bahasa Inggris (Y) adalah sebesar 9,9\%, sisanya $(90,1 \%)$ karena pengaruh faktor lain.

Sedangkan untuk pengujian hipotesis melalui analisis regresi diperoleh hasil perhitungan terlihat pada Tabel 4.5. Dari Tabel 4.5 diperoleh persamaan garis regresi yang merepresentasikan pengaruh variabel $\mathrm{X}$ terhadap variabel $\mathrm{Y}$, yaitu $\widehat{\mathbf{Y}}=54,543+(-0,481) \mathrm{X}$. Menurut ketentuan yang ada, kriteria signifikansi regresi tersebut adalah “jika Sig < 0.05 maka $\mathrm{H}_{0}$ ditolak" atau “jika $\mathbf{F}_{\text {hitung }}>\mathbf{F}_{\text {tabel }}$ maka $\mathrm{H}_{0}$ ditolak", yang berarti bahwa koefisien regresi tersebut signifikan, dengan kata lain terdapat pengaruh yang signifikan variabel bebas $\mathrm{X}$ terhadap variabel terikat Y. Sedangkan nilai $\mathbf{F}_{\text {tabel }}$ adalah nilai tabel distribusi $\mathbf{F}$ untuk taraf nyata $5 \%$ dengan derajat pembilang $(\mathrm{k})=1$ dan derajat penyebut $(n-k-1)=38$, dimana $n$ adalah banyaknya responden, dan $\mathrm{k}$ adalah banyaknya variabel bebas.

Dari Tabel 4.6. terlihat bahwa nilai Sig $=0.007$ dan $\mathbf{F}_{\text {hitung }}=0,375$ sedangkan $\mathbf{F}_{\text {tabel }}=0,37$. Karena nilai Sig $<0,05$ dan $\mathbf{F}_{\text {hitung }}>\mathbf{F}_{\text {tabel }}$ maka $\mathrm{H}_{0}$ diterima yang berarti bahwa koefisien regresi tersebut signifikan. Dengan kata lain bahwa terdapat pengaruh yang signifikan variabel bebas Komunikasi Keluarga (X) terhadap 
Variabel terikat Prestasi Belajar Bahasa Inggris (Y).

Dari hasil pengujian korelasi maupun regresi tersebut maka bisa disimpulkan bahwa terdapat pengaruh yang signifikan variabel bebas komunikasi Keluarga (X) terhadap prestasi belajar Bahasa Inggris (Y).

Penelitian ini untuk mengetahui pengaruh komunikasi keluarga terhadap prestasi belajar Bahasa Inggris

Dari deskripsi data setelah dilakukan analisis korelasi diperoleh koefisien korelasi sebesar 1,000, setelah dilakukan pengujian dengan program SPSS terbukti bahwa koefisien korelasi tersebut signifikan. Hal ini berarti bahwa terdapat pengaruh variabel bebas $\mathrm{X}$ (Komunikasi keluarga) terhadap variabel terikat $\mathrm{Y}$ (prestasi belajar Bahasa Inggris peserta didik).

Sedangkan dari analisis regresi diperoleh persamaan garis regresi $\widehat{\mathbf{Y}}$ $=54,543+0,375 X$. Nilai konstanta $=$ 54,543 menunjukkan bahwa siswa dengan Komunikasi keluarga paling rendah sulit untuk bisa meraih prestasi belajar yang baik, sedangkan nilai koefisien regresi (tolerance) sebesar 1,000 dan (VIF) 1,000 menunjukkan bahwa tidak terdapat pengaruh positif variabel bebas $\mathrm{X}$ (Komunikasi keluarga) terhadap variabel terikat Y (prestasi belajar Bahasa Inggris peserta didik). Setelah dilakukan pengujian linieritas garis regresi dengan menggunakan program SPSS diperoleh bahwa garis regresi tersebut linier.

Dari pengujian signifikansi koefisien regresi yang juga dilakukan dengan program SPSS diperoleh bahwa koefisien regresi tersebut signifikan, yaitu ditunjukkan oleh nilai Sig $=0,544$ dan $\mathbf{F}_{\text {hitung }}=0,375$ sedangkan $\mathbf{F}_{\text {tabel }}=3,07$ sehingga nilai Sig $<0,05$ dan $\mathbf{F}_{\text {hitung }}>\mathbf{F}_{\text {tabel }}$ atau regresi tersebut signifikan, yang berarti benar bahwa terdapat pengaruh yang positif variabel bebas $\mathrm{X}$ (Komunikasi keluarga) terhadap variabel terikat Y (Prestasi Belajar Bahasa Inggris).

Hasil penelitian ini sesuai dengan ungkapan dari Slameto bahwa faktor prestasi belajar dipengaruhi oleh faktor luar dan faktor dalam. Komunikasi keluarga adalah salah satu faktor luar yang merupakan 
penggerak dalam usaha meraih prestasi setinggi mungkin. Komunikasi keluarga pada peserta didik membuat peserta didik semakin serius dalam mempelajari sesuatu yang diinginkan, dan dari komunikasi keluarga tersebut tentunya akan meningkatkan prestasi belajar Bahasa Inggris peserta didik. Dari komunikasi keluarga yang baik akan membentuk keluarga yang seimbang dan selalu memberikan peluang paling besar untuk memperdayakan potensi anak-anaknya. Keluarga seimbang memberikan kesempatan kepada anak-anaknya untuk berkreasi, menggali potensi dan melakukan berbagai kegiatan yang bernilai positif. Orangtua melalui komunikasi yang terbangun secara intensif senantiasa membuka diri untuk dialog bahkan perkembangan apapun dalam keluarga selalu dikomunikasikan secara intensif.

Sedangkan prestasi belajar adalah suatu kemampuan intelektual siswa yang mengandung kemampuan dan keterampilan berkaitan dalam upaya untuk dapat menyelesaikan suatu program pembelajaran. Komunikasi keluarga adalah sebagai usaha yang bertujuan untuk mencapai hasil dengan membandingkan beberapa ukuran keunggulan. Keunggulan disini merupakan perbandingan antara prestasi yang dicapai sendiri atau prestasi yang sudah dicapai sebelumnya. Sedangkan prestasi belajar Bahasa Inggris adalah tingkat pencapaian kemampuan peserta didik pada materi Bahasa Inggris, serta pencapaian ketrampilan dan sikap yang terkait dengan pengetahuan tentang Bahasa Inggris.

Jika peserta didik ingin memperoleh prestasi belajar yang tinggi maka peserta didik tersebut harus melakukan komunikasi keluarga dengan baik sehingga prestasi yang tinggi bisa diraih.

Dari informasi kuantitatif dan teori tersebut maka peneliti berasumsi bahwa terdapat pengaruh positif komunikasi keluarga terhadap prestasi belajar Bahasa Inggris peserta didik.

\section{PENUTUP}

Pada bagian kesimpulan ini, penulis uraikan secara singkat hasil penelitian yang diperoleh di 
lapangan. Setelah diadakan penelitian dan analisis data tentang "Pengaruh Komunikasi Keluarga terhadap Prestasi Belajar Bahasa Inggris" dapat ditarik kesimpulan sebagai berikut:

1. Terdapat pengaruh komunikasi keluarga (X) terhadap prestasi belajar bahasa inggris (Y) dengan mendasar dari pengujian hipotesis diperoleh bahwa nilai $\mathrm{Sig}=0.544$ dan $t_{\text {hitung }}=0,375$, sedangkan $t_{\text {tabel }}$ $=3,07$. Karena nilai Sig $>0,05$ dan $\mathrm{t}_{\text {hitung }}<\mathrm{t}_{\text {tabel }}$ maka $\mathrm{H}_{0}$ diterima yang berarti terdapat pengaruh yang signifikan variabel bebas $\mathrm{X}$ (Komunikasi Keluarga) terhadap variabel terikat Y (Prestasi Belajar Bahasa Inggris).

2. Sedangkan kekuatan sumbangan ditunjukan dengan koefisien determinasi sebesar 9,9\% yang menunjukan bahwa kontribusi komunikasi keluarga terhadap prestasi belajar Bahasa Inggris sebesar $9,9 \%$

3. Dari pengujian signifikansi koefisien regresi juga signifikan, yaitu ditunjukkan oleh nilai $\mathbf{S i g}=$ 0.000 dan $\mathbf{F}_{\text {hitung }}=33,259$, sedangkan $\quad \mathbf{F}_{\text {tabel }}=3,07$ sehingga nilai Sig $<0,05$ dan $\mathbf{F}_{\text {hitung }}>\mathbf{F}_{\text {tabel }}$ atau regresi tersebut signifikan, yang berarti benar bahwa terdapat pengaruh yang positif variabel bebas X (Komunikasi keluarga) terhadap variabel terikat $\mathrm{Y}$ (Prestasi Belajar Bahasa Inggris).

Dengan demikian komunikasi keluarga berperan sangat penting dalam menentukan dan meningkatkan prestasi belajar bahasa inggris peserta didik.

Berdasarkan temuan penelitian di atas yang didasarkan pada analisis data penelitian, bahwa prestasi belajar Bahasa Inggris peserta didik dapat ditingkatkan dengan cara meningkatkan komunikasi keluarga.

\section{DAFTAR PUSTAKA}

Arikunto, Suharsimi. (1988). Dasardasar Evaluasi Pendidikan. Jakarta: Bina Aksara

Arikunto, S. (2008). Dasar-Dasar Evaluasi Pendidikan. Jakarta: Bumi Aksara.

Bernadib, Sutari Imam. (2000). Ilmu Pendidikan Teoritis dan Praktis. Yogyakarta: F.P Yogyakarta

Slameto. (2003). Belajar dan Faktorfaktor yang Mempengaruhinya. Jakarta: Rineka Cipta. 
Slameto. (1995). Belajar dan Faktorfaktor yang Mempengaruhinya. Jakarta. Rineka Cipta.

Soekamto, Toeti. (1992). Prinsipprinsip Pembelajaran. (outline). $\underline{w w w . u t . a c . i d}$

Sudjana. (2002). Metoda Statistika. Bandung: Tarsito

Sudjana, Nana. (2005). Dasar-dasar Proses Belajar Mengajar. Bandung: Sinar Baru Algensindo.

Sutikno, M. Sobry. (2004). Belajar dan Pembelajaran. Bandung: Prospect.
Sudjana, Nana. (1991). Penelitian Hasil Proses Belajar Mengajar. Bandung: Remaja Rosdakarya.

Sudjana Nana. (2002). Dasar-Dasar Proses Belajar Mengajar. Bandung: Sinar Baru.

Winkel, WS. (1986). Psikologi Pengajaran. Gramedia. Jakarta.

Winkel, W. S. (1996). Psikologi Pendidikan dan Evaluasi Pendidikan. Jakarta : Gramedia. 
PENGARUH KOMUNIKASI KELUARGA TERHADAP PENGUASAAN BAHASA INGGRIS PESERTA DIDIK KELAS X DI SMK PGRI 1 TAMBUN KECAMATAN TAMBUN SELATAN KABUPATEN BEKASI 